\title{
Correction to: Brazil-Africa Relations in the 21st Century: From Surge to Downturn and Beyond
}

\author{
Mathias Alencastro and Pedro Seabra
}

\section{Correction to:}

\section{Alencastro, P. Seabra (eds.), Brazil-Africa Relations in the 21st Century, https://doi.org/10.1007/978-3-030-55720-1}

This book was inadvertently published without updating the following:

\section{Corrections:}

Chapter 10: author Robert I. Rotberg was incorrect in the index (page xi), in the author bios (page xiv), and in page 151. This has now been updated.

Page 1: email address (m.dealencastro@gmail.com) was missed for the corresponding author Dr Mathias Alencastro. This has now been updated.

Page 6, second paragraph: the term "lusophone" has now been corrected as "Lusophone".

Page 7, third paragraph, first line: when introducing the Conclusion, there was no link to the corresponding page. This has now been updated.

Page 9: email address (thiagokrause@ gmail.com) was missed for the corresponding author, Thiago Krause. This has now been updated.

The updated online versions of this book can be found at https://doi.org/10.1007/978-3-030-55720-1 
Page 39: the reference to Barnaby Dye and Mathias Alencastro's work has now been corrected as "Dye, Barnaby Joseph, and Mathias Alencastro. 2020. Debunking Brazilian exceptionalism in its Africa relations: Evidence from Angola and Tanzania. Global Society 34 (4): 425-446."

Page 40: the reference to Camila et al's work has now been corrected as "Santos, Camila dos, Maíra Siman, and Marta Fernández. 2019. Two Brazils': Renegotiating Subalternity through south-south cooperation in Angola. Brazilian Political Science Review 13 (1): online."

Page 43: email address (adriana.schor@gmail.com) was missed for the corresponding author Adriana Schor. This has now been updated.

Page 55: email address (m.dealencastro@gmail.com) was missed for the corresponding author Dr Mathias Alencastro. This has now been updated.

Page 69, first paragraph, fourth sentence has now been corrected as "Between 2015 and 2017, the global value of the project portfolio of the company fell almost by half from US\$28 to US\$15 billion."

Page 70: the reference to Barnaby Dye and Mathias Alencastro's work has now been corrected as "Dye, Barnaby Joseph, and Mathias Alencastro. 2020. Debunking Brazilian exceptionalism in its Africa relations: Evidence from Angola and Tanzania. Global Society 34 (4): 425-446."

Page 83: footnote 28 has now been corrected as "Interview, senior official, Odebrecht, 2016; interviews, senior and junior officials, Itamaraty, 2015-2016."

Page 92: the reference to Barnaby Dye and Mathias Alencastro's work has now been corrected as "Dye, Barnaby Joseph, and Mathias Alencastro. 2020. Debunking Brazilian exceptionalism in its Africa relations: Evidence from Angola and Tanzania. Global Society 34 (4): 425-446."

Page 95: email address (danilomarcondes@gmail.com) was missed for the corresponding author Danilo Marcondes. This has now been updated.

Page 113: email address (laura.waisbich@gmail.com) was missed for the corresponding author Laura Trajber Waisbich. This has now been updated.

Page 118, first paragraph, first line has now been corrected as "Professional NGOs and think thanks based in São Paulo, Rio de Janeiro and Brasilia (...)".

Page 131: the reference to Barnaby Dye and Mathias Alencastro's work has now been corrected as "Dye, Barnaby Joseph, and Mathias Alencastro. 2020. Debunking Brazilian exceptionalism in its Africa relations: Evidence from Angola and Tanzania. Global Society 34 (4): 425-446." 
Page 151: email address (robert_rotberg@harvard.edu) was missed for the chapter author Robert I. Rotberg. This has now been updated.

Page 156, first paragraph, second sentence has now been corrected as "Together, they revitalized and/or inaugurated the Zone of Peace and Cooperation in the South Atlantic (ZOPACAS - Zona de Paz e Cooperação do Atlântico Sul)" (...). This in turn adds a second instance to the index count on ZOPACAS, on page 168. 